\title{
Site Specific Nutrient Management for Maize on Ultisols Lampung
}

\author{
Andarias Makka Murni ${ }^{1}$, Julie Mae Pasuquin ${ }^{2}$ and Christian Witt ${ }^{2}$ \\ Received 30 November 2009 / accepted 4 January 2010
}

\begin{abstract}
Site Specific Nutrient Management for Maize on Ultisols Lampung (AM Murni, JM Pasuquin, and C Witt): Lampung is the third major maize producing province in Indonesia after East Java and Central Java. In Lampung maize is cultivated mainly in upland areas with ultisols and only some cultivated on paddy field as a secondary crop in the dry season. The average maize yield in Lampung is still $3.4 \mathrm{Mg} \mathrm{ha}^{-1}$ bellow yield potential of $7-10 \mathrm{Mg} \mathrm{ha}^{-1}$. To increase the productivity of maize through site-specific nutrient management (SSNM), on-farm trials were conducted in five locations in Lampung i.e. four locations in Central Lampung District (Sidowaras, Binjai Ngagung, Watu Agung and Balai Rejo) and one location in South Lampung District (Trimulyo, Tegineneng Sub District) during the 2004/2005, 2005/2006 and 2006/2007 rainy seasons. The experimental setup followed a standard protocol at all sites and included nutrient omission plots (PK, NK, NP) to estimate indigenous nutrient supplies, an NPK plot to measure yield response to fertilizer application, and a farmers' fertilizer practice (FFP) plot in each farmer's field. An SSNM treatment plot was included in the second and third seasons. Each of the above treatments was paralleled by a plot with improved crop management practice (ICM), i.e. higher planting density, addition of lime, and addition of magnesium. Results showed that yield response to fertilizer $\mathrm{N}, \mathrm{P}$ and $\mathrm{K}$ application in these sites were: $\mathrm{N}=2.3-4.1 \mathrm{Mg} \mathrm{ha}^{-1} ; \mathrm{P}=0.6-2.0 \mathrm{Mg} \mathrm{ha}^{-1}$; $\mathrm{K}=0.3-2.4 \mathrm{Mg} \mathrm{ha}^{-1}$. Attainable yield in the three seasons on average ranged from $7.6 \mathrm{Mg} \mathrm{ha}^{-1}$ to $10.6 \mathrm{Mg} \mathrm{ha}^{-1}$. Yield in the SSNM treatment (with or without ICM) was significantly higher than the FFP indicating great opportunities for farmers to increase productivity and profitability with improved nutrient and crop management.
\end{abstract}

Keywords: Agronomic efficiency, fertilizer, nutrient management, site specific, yield response

\section{INTRODUCTION}

Maize is an important economical crop in Indonesia and the acreage is currently about 3.5 million hectares that could produce 14 million tons of maize. The low yield attained $\left(3.2 \mathrm{Mg} \mathrm{ha}^{-1}\right)$ is due to low of soil fertility, pest, diseases, weeds, low use of fertilizers, and low yielding varieties (Swastika $e t$ al. 2004).

Lampung is one of the major maize growing provinces in Indonesia that largely grow maize as commercial crop for feed. In Lampung maize is planted mainly in upland areas and only some planted on paddy field as a secondary crop in the dry season. Potential area in this region is about 674,238 hectares; however, only 320,008-399,827 hectares are planted every year (Lampung in Figure 2006). The main maize production districts are East Lampung, South Lampung and Central Lampung with soil type is mainly ultisols.

The average maize yield in Lampung is $3.4 \mathrm{Mg}$ $\mathrm{ha}^{-1}$, which is higher than the national average (3.2 $\left.\mathrm{Mg} \mathrm{ha}^{-1}\right)$. However, yield potential can be attained of $7-10 \mathrm{Mg} \mathrm{ha}^{-1}$. The yield of maize is dependent on variety, season, soil fertility, and crop management implemented by farmers. Production constraints are diseases (downy mildew, ear rot, sheath blight and rust), insect pests, weeds, low soil fertility and drought (Swastika et al. 2004).

The general fertilizer recommendation for maize in Lampung is $300 \mathrm{~kg}$ urea, $100-150 \mathrm{~kg} \mathrm{SP}-36$ and $100 \mathrm{~kg} \mathrm{KCl} \mathrm{ha} a^{-1}$, but most farmers apply urea and SP-36 without $\mathrm{KCl}$ while some farmers use urea and manure without SP-36 and $\mathrm{KCl}$. This general fertilizer recommendation and current farmers' fertilizer

\footnotetext{
${ }^{1}$ Lampung Assessment Institute for Agricultural Technology (AIAT), J1. Z.A. Pagar Alam No. 1A, Rajabasa 35144, e-mail: andarias_makka@yahoo.co.id

${ }^{2}$ International Plant Nutrition Institute (IPNI) Southeast Asia Program, e-mail: jmpasuquin@ipni.net and cwitt@ipni.net
}

J Trop Soils, Vol. 15, No. 1, 2010: 49-54

ISSN 0852-257X 
practice are not based on the nutrient requirements of the maize crop and the nutrients available in the soil. The application of fertilizer does not meet the crop's need. Application of adequate quantities of nutrients is a key aspect in increasing maize productivity and production, but those nutrients should be balanced based on the plant requirement. According to Sawyer in Ferguson et al. (2002), sitespecific management of soil fertility inputs is an attractive and intuitive approach to increasing fertilizer use efficiency.

The concept for site-specific nutrient management (SSNM) was developed for irrigated rice in Asia (Dobermann et al. 2002; Witt et al. 2002). SSNM has been suggested as a method to improve nutrient use efficiency by the plant. For example, Ferguson et al. (2002) stated that site specific nitrogen management is a means of further increasing the efficiency in which $\mathrm{N}$ fertilizers are used and reducing environmental impact.

To increase the productivity of maize through site-specific nutrient management, on-farm experiments were conducted in the ultisols of several areas of Lampung during the rainy season in 2004/ 2005, 2005/2006, and 2006/2007.

\section{MATERIALS AND METHODS}

\section{Study Area}

On-farm experiments were conducted during the rainy seasons of 2004/2005, 2005/2006, and 2006/ 2007 in five locations i.e. four locations in Central Lampung, namely Sidowaras, Binjai Ngagung, Watu Agung and Balai Rejo and one location in Trimulyo (Tegineneng Sub District), Pesawaran. Soils in Sidowaras, Binjai Ngagung and Trimulyo belong to the Kandiudult soil type while soils in Watu Agung and Balai Rejo belong to Kanhapludult soil (Isa et al. 2005) in which those are include ultisols.

\section{Experimental Setup}

The experimental setup followed a standard protocol at all locations and included nutrient omission plots (PK, NK, NP) to estimate indigenous nutrient supplies, an NPK plot to measure yield response to fertilizer application, and a farmers' fertilizer practice (FFP) plot in each farmer's field. Preliminary estimates of yield responses and agronomic efficiencies from omission plots in the first season were used to calculate field-specific fertilizer recommendations for maize that were evaluated in an SSNM treatment plot in the following season. Each of the above treatments was paralleled by a plot with improved crop management practice (ICM), i.e. higher planting density, addition of lime, and addition of magnesium. Farms/locations are used as replicates. Individual plots sizes were $6 \mathrm{~m} \times 6 \mathrm{~m}$ for treatments of PK, PK + ICM, NK, NK + ICM, NP, NP + ICM, NPK and NPK + ICM and $6 \mathrm{~m} \times 24 \mathrm{~m}$ for SSNM, SSNM + ICM, FFP, and FFP + ICM. In season 1 (2004/2005), the ICM treatment was the application of $1.5 \mathrm{Mg} \mathrm{ha}^{-1}$ of lime and higher plant population (75 $\mathrm{cm}$ between rows and 17.5 between plants in a row) than the regular treatments (plant spacing of $75 \mathrm{~cm} \mathrm{x}$ $20 \mathrm{~cm})$. In the second and third seasons $(2005 / 2006-$ 2006/2007), the ICM treatment was the application of $1.5 \mathrm{Mg} \mathrm{ha}^{-1}$ of lime and $20.4 \mathrm{~kg} \mathrm{ha}^{-1}$ of magnesium $(\mathrm{Mg})$. Plant spacing for all treatments was $75 \mathrm{~cm} \mathrm{x}$ $20 \mathrm{~cm}$. Fertilizer rates in the omission plots, NPK, SSNM, and FFP treatments are shown in Table 1.

Urea was used as the $\mathrm{N}$-source in plots with $\mathrm{N}$ application (NK, NP, NPK, and SSNM plots). Basal $\mathrm{N}(30 \%)$ was applied shortly after emergence (7 days after planting = dap), with side-dressings at V6 (40\%) and V10 (30\%) stages of maize, dibbled $\pm 5 \mathrm{~cm}$ deep as band along the maize rows. For plots with $\mathrm{P}$ application (PK, NP, NPK, and SSNM plots), the Psource was SP-36. All P fertilizer was applied together with the first $\mathrm{N}$ application shortly after emergence. The source of potassium in PK, NK, NPK, and SSNM plots was $\mathrm{KCl}$. Half of $\mathrm{K}$ fertilizer was applied with the first $\mathrm{N}$ application shortly after emergence and the other half during the V10 stage, dibbled $\pm 5 \mathrm{~cm}$ deep as band along the maize rows. Farmers' fertilizer application were splits twice for $\mathrm{N}$ (urea) that is the first application at 12 dap and the second application at 30 dap, while $\mathrm{P}(\mathrm{SP} 36)$ and $\mathrm{K}(\mathrm{KCl})$ applied all at 12 dap together with the first $\mathrm{N}$ application.

Before planting, composite soil samples were taken at $0-20 \mathrm{~cm}$ depth from each location. A composite soil sample was a mixture of 25 soil cores that were taken across the whole field following a zigzag pattern. Nutrients and fractions analyzed were particle size (clay, silt, sand; pipette method), soil organic C (Walkley-Black), total soil $\mathrm{N}$ (Kjeldahl), CEC and exchangeable $\mathrm{K}, \mathrm{Na}, \mathrm{Ca}$ and $\mathrm{Mg}\left(1 \mathrm{~N} \mathrm{NH}_{4}^{-}\right.$ acetate), $\mathrm{pH}(\mathrm{KCl}, 1: 1), \mathrm{pH}\left(\mathrm{H}_{2} \mathrm{O}, 1: 1\right)$, Olsen-P $(0.5$ $\left.M \mathrm{NaHCO}_{3}, \mathrm{pH} 8.5\right)$, Bray-1 $\mathrm{P}\left(0.03 \mathrm{M} \mathrm{NH}_{4} \mathrm{~F}+0.025\right.$ $M \mathrm{HCl}$ ), and exchangeable $\mathrm{Al}$.

Management practices implemented were based on the best recommendations and technologies 
Table 1. Fertilizer rate and application in the treatments.

\begin{tabular}{|c|c|c|c|c|c|}
\hline \multirow{2}{*}{ Treatments/season } & \multicolumn{3}{|c|}{ Fertilizer rate $\left(\mathrm{kg} \mathrm{ha}^{-1}\right)$} & \multirow{2}{*}{$\begin{array}{c}\text { Lime } \\
\left(\mathrm{Mg} \mathrm{ha}^{-1}\right)\end{array}$} & \multirow{2}{*}{$\underset{\left(\mathrm{kg} \mathrm{ha}^{-1}\right)}{\operatorname{Magnesium}}$} \\
\hline & $\mathrm{N}$ & $\mathrm{P}_{2} \mathrm{O}_{5}$ & $\mathrm{~K}_{2} \mathrm{O}$ & & \\
\hline $\begin{array}{l}\text { Season1 (2004/2005): } \\
\text { - Omision Plot }\end{array}$ & 200 & 80 & 120 & 0 & 0 \\
\hline - Omision Plot + ICM & 250 & 92 & 181 & 1.5 & 0 \\
\hline - FFP & 135 & 67 & 48 & 0 & 0 \\
\hline - FFP+ICM & 135 & 67 & 48 & 1.5 & 0 \\
\hline \multicolumn{6}{|l|}{ Season $2(2005 / 2006)$ : } \\
\hline - Omision Plot & 200 & 80 & 120 & 0 & 0 \\
\hline - Omision Plot + ICM & 200 & 80 & 120 & 1.5 & 24.5 \\
\hline -SSNM & 129 & 71 & 148 & 0 & 0.0 \\
\hline - SSNM+ICM & 129 & 71 & 148 & 1.5 & 24.5 \\
\hline - FFP & 180 & 41 & 22 & 0 & 0 \\
\hline \multicolumn{6}{|l|}{ Season 3 (2006/2007): } \\
\hline - Omision Plot & 200 & 80 & 120 & 0 & 0 \\
\hline - Omision Plot + ICM & 200 & 80 & 120 & 1.5 & 24.5 \\
\hline - SSNM & 152 & 80 & 112 & 0 & 0 \\
\hline - SSNM+ICM & 152 & 80 & 112 & 1.5 & 24.5 \\
\hline -FFP & 235 & 34 & 43 & 0 & 0 \\
\hline
\end{tabular}

Note: $\mathrm{ICM}=$ crop management practice, $\mathrm{SSNM}=$ site-specific nutrient management, FFP $=$ farmers' fertilizer practice.

available at each location, following the concept of integrated crop management. Maize varieties planted in the trial were Pioneer 21 at location one (Sidowaras) and BISI-2 at other locations (Binjai Ngagung, Watu Agung, Balai Rejo and Trimulyo). All treatments received full control from weeds, pests and diseases.

\section{Data Analysis}

Grain yield was measured at final harvest around 7-10 days after physiological maturity (R6). Grain yield data were analyzed using Duncan Multiple Range Test (DMRT) to determine the differences among treatments. Yield responses to fertilizer NPK application were obtained from the difference between the yield in NPK (+/-ICM) and the relevant omission plot (0-N, 0-P, 0-K) (Cassman et al. 1998) with the formula:

$$
\ddot{\mathrm{A} Y}=\mathrm{Y}_{\mathrm{NPK}}-\mathrm{Y}_{0 \mathrm{X}},
$$

Where: $\ddot{A} Y=$ Yield $\left(\mathrm{Mg} \mathrm{ha}^{-1}\right)$ response to $\mathrm{x}$ fertilizer; $\mathrm{Y}_{\mathrm{NPK}}=$ Yield $\left(\mathrm{Mg} \mathrm{ha}^{-1}\right)$ in a plot that received fertilizer nutrient $\mathrm{X}$; and $\mathrm{Y}_{0 \mathrm{X}}=$ Yield $\left(\mathrm{Mg} \mathrm{ha}^{-1}\right)$ in a plot without $\mathrm{X}$ fertilizer.

Agronomic efficiency was measured as the amount of crop yield increase per unit nutrient applied (Cassman et al. 1998) with the formula:

$$
\mathrm{AE}_{\mathrm{X}}=\left(\mathrm{Y}_{\mathrm{NPK}}-\mathrm{Y}_{0 \mathrm{X}}\right) / \mathrm{F}_{\mathrm{X}}
$$

where: $\mathrm{AE}_{\mathrm{X}}=$ Agronomic efficiency of nutrient $\mathrm{X}$ $\left(\mathrm{kg} \mathrm{kg}^{-1}\right) ; \mathrm{Y}_{\mathrm{NPK}}=$ Yield $\left(\mathrm{kg} \mathrm{ha}^{-1}\right)$ in a plot that received fertilizer nutrient $\mathrm{X}\left(\mathrm{kg} \mathrm{ha}^{-1}\right) ; \mathrm{Y}_{\mathrm{oX}}=$ Yield in a plot without fertilizers nutrient $\mathrm{X}$ addition $\left(\mathrm{kg} \mathrm{ha}^{-1}\right)$; and $\mathrm{Fx}=$ Rate $\left(\mathrm{kg} \mathrm{ha}^{-1}\right)$ of nutrient $\mathrm{X}$ fertilizers applied.

\section{RESULTS AND DISCUSSION}

\section{Soil Properties}

Soil properties in the experimental sites are shown in Table 2. On average, soils are characterized as having clay loam texture, slightly acidic $\left(\mathrm{pH} \mathrm{H}_{2} \mathrm{O}: 5.0\right)$, with very low organic carbon $\left(11.7 \pm 4.7 \mathrm{~g} \mathrm{~kg}^{-1}\right)$ and total $\mathrm{N}\left(0.94 \pm 0.32 \mathrm{~g} \mathrm{~kg}^{-1}\right)$, low to high status of $\mathrm{P}$ potential, $\mathrm{P}$ Olsen and $\mathrm{P}$ Bray-1 with soil test value of $428 \pm 256 ; 49 \pm 29$ and $40 \pm 22 \mathrm{mg} \mathrm{kg}^{-1} \mathrm{P}_{2} \mathrm{O}_{5}$ respectively, and low exchangeable $\mathrm{K}(0.19 \pm 0.16$ cmol (+) $\left.\mathrm{kg}^{-1}\right)$.

The clay loam texture of the sites indicates a good environment for root development for maize, and there is an opportunity to improve soil and crop management practices trough site specific nutrient management. The site shows low content of soil organic carbon (SOC) that indicated low soil organic matter (SOM). SOM in intensify cultivated land as in the experimental site very strongly related to cropresidue management, tillage system and crop rotation implemented by farmers. Increased tillage of 
Table 2. Soil Properties in the experimental site (average of and 5 locations).

\begin{tabular}{lc}
\hline \multicolumn{1}{c}{ Soil Properties } & Mean $(0-20 \mathrm{~cm})$ \\
\hline Sand $(\%)$ & $32 \pm 29$ \\
Silt $(\%)$ & $21 \pm 12$ \\
Clay (\%) & $47 \pm 25$ \\
Organic Matter & \\
$\mathrm{C}\left(\mathrm{g} \mathrm{kg}^{-1}\right)$ & $11.7 \pm 4.7$ \\
$\mathrm{~N}\left(\mathrm{~g} \mathrm{~kg}^{-1}\right)$ & $0.94 \pm 0.32$ \\
$\mathrm{C} / \mathrm{N}$ & $13 \pm 1.79$ \\
Soil nitrate N $\left(\mathrm{g} \mathrm{kg}^{-1}\right)$ & $128.2 \pm 26.3$ \\
$\mathrm{P} \mathrm{HCl} 25 \%\left(\mathrm{mg} \mathrm{kg}^{-1}\right)$ & $428 \pm 256$ \\
$\mathrm{P}-\mathrm{Olsen}\left(\mathrm{mg} \mathrm{kg}^{-1} \mathrm{P}_{2} \mathrm{O}_{5}\right)$ & $49 \pm 29$ \\
$\mathrm{P}-\mathrm{Bray}\left(\mathrm{mg} \mathrm{kg}^{-1}\right)$ & $40 \pm 22$ \\
$\mathrm{pH}\left(\mathrm{H}_{2} \mathrm{O}\right)$ & $5.0 \pm 0.34$ \\
$\mathrm{Al}{ }^{3+}\left(\mathrm{cmol} \mathrm{kg}^{-1}\right)$ & $0.07 \pm 0.16$ \\
$\mathrm{~K} \mathrm{Exchangeable}(\mathrm{cmol} \mathrm{kg}$ & $0.19 \pm 0.16$ \\
$\mathrm{CEC}$ & $10.95 \pm 3.93$ \\
Base Saturation $(\%)$ & $54 \pm 9$ \\
\hline
\end{tabular}

the soil decreases organic matter, because tillage increases aeration, which leads to drier soils and greater rates of decomposition (Zibilske and Bradford 2007; Gale and Cambardella 2000). In case low of $\mathrm{SOM}$ in the site it seems due to farmers burnt their crops residue, full tillage practice and without residue incorporation in to the soil.

Very low of soil total $\mathrm{N}$ in the sites indicated that the soil of maize area is low of indigenous nutrient supply. Total nitrogen (TN) is a measure of both inorganic and organic forms of nitrogen. Levels of $\mathrm{N}$ vary with temperature and moisture in the same way as levels of SOM, that is, $\mathrm{N}$ increases with cooler temperatures and more moisture. $\mathrm{N}$ as well $\mathrm{C}$ concentration in the soil could be affected by soil and residue management practices.

Zibilske and Bradford (2007) reported that conservation tillage (no tillage) treatments resulted in highly significant concentrations of organic $\mathrm{N}$, compared with the conventional plow tillage and ridge tillage treatment. In case of maize cultivated in Lampung particularly in the experimental site, farmers do practice intensive tillage, thus the low of $\mathrm{N}$ in the soil can be attributed to this management practice.

$P$ soil content vary which is showed by high range of $\mathrm{P}$ content both $\mathrm{P}$ potential and $\mathrm{P}$ available. This condition perhaps due to the difference rate of $\mathrm{P}$ fertilizer was applied in the farmers field in which resulted the variation residue $P$ in the soil. In the area in which the soil $\mathrm{P}$ is low, response of maize to $\mathrm{P}$ fertilization would be high but in contrast to the high soil $\mathrm{P}$ the response of maize to $\mathrm{P}$ fertilization is low. The high $\mathrm{P}$ available indicated that the requirement of $P$ fertilizer to produce the high yield of maize in the site is rather low, in other words, plant is low responses to the high rate of $\mathrm{P}$ fertilizer.

The quantity of exchangeable $\mathrm{K}$ soil in the site is very low. Exchangeable K usually reflects the soil's readily available $\mathrm{K}$ and it includes the water soluble $\mathrm{K}$. As the level of soil decreases, the crop response to applied $\mathrm{K}$ fertilizer increases. The low of $\mathrm{K}$ in the site also related to the residue management by farmers. Zero to low rate of $\mathrm{K}$ fertilizer applied by farmers and without residue incorporated in a long term of intensified cultivated maize area can cause the decline of soil $\mathrm{K}$.

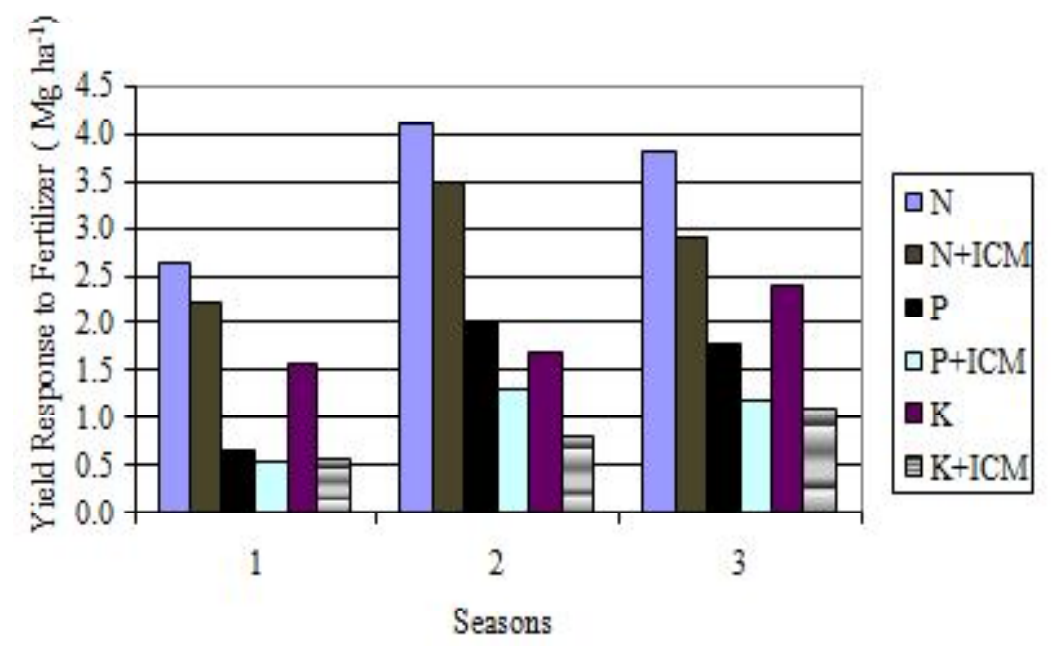

Figure 1. Yield response to N, P, and K fertilizers and application based on NPK (+/- ICM). 


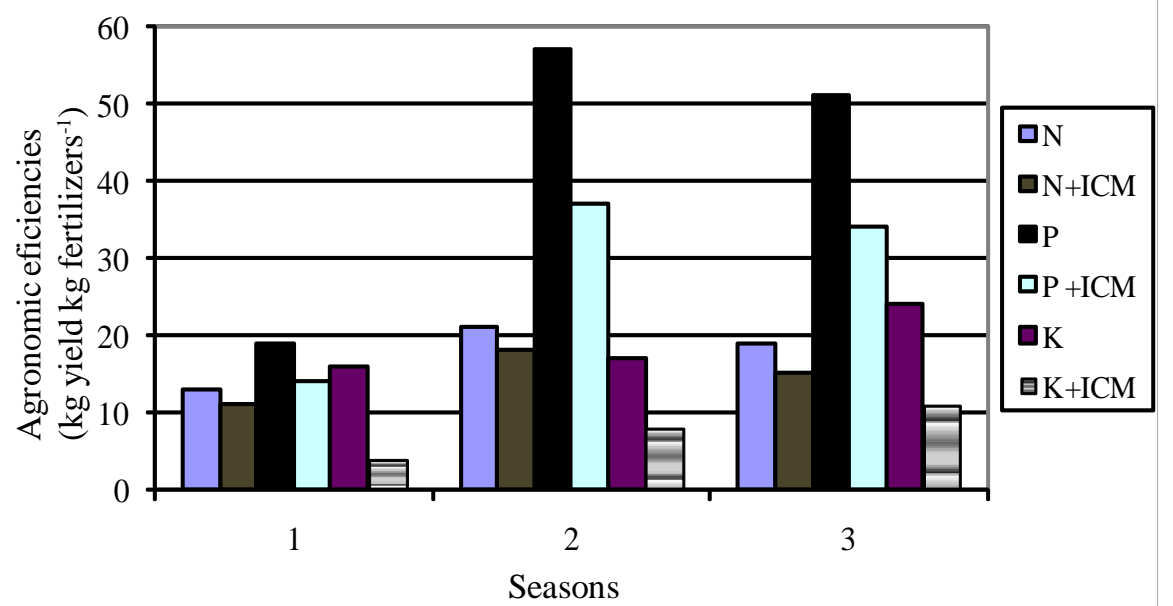

Figure 2. Agronomic efficiencies N, P, and K based on NPK and SSNM treatments.

\section{Yield Response to Fertilizer Application}

Yield response to fertilizer application was in the order $\mathrm{N}>\mathrm{K}>\mathrm{P}$ ranging on average from 2.3 to $4.1 \mathrm{Mg}$ $\mathrm{ha}^{-1}$ for $\mathrm{N}$, from 0.5 to $2.0 \mathrm{Mg} \mathrm{ha}^{-1}$ for $\mathrm{P}$, and from 0.6 to $2.4 \mathrm{Mg} \mathrm{ha}^{-1}$ for $\mathrm{K}$ (Figure 1).

The magnitude of yield response to applied fertilizer is dependent on the indigenous nutrient supply in which consistent to the soil properties (as shown in Table 2) and climatic conditions during the growing season. Yield responses to N, P, and $\mathrm{K}$ were higher in season 2 and season 3 where growing conditions were more favorable, as indicated by the higher yields obtained in the NPK and SSNM treatment plots as compared to season 1 . Yield responses to fertilizer application are very variable among fields (data not shown) and/or seasons, thus, a nutrient management strategy that is robust to handle such variability is clearly required.

\section{Agronomic Efficiencies}

Agronomic efficiency (AE) is one of several indicators of nutrient use efficiency. It is expressed as the yield increase per unit fertilizer applied (kg grain per $\mathrm{kg}$ fertilizer). Agronomic efficiency is a measure of the ability of a plant to transform the amount of fertilizer or nutrients applied into economic yield (grain). It is a good indicator of the congruence between plant nutrient demand and the quantity of nutrient released from applied fertilizer. Figure 2 shows the agronomic efficiency for $\mathrm{N}, \mathrm{P}$, and $\mathrm{K}$ measured from the NPK treatment plots. On average, agronomic efficiencies ranged from 9 to $21 \mathrm{~kg}$ grain per $\mathrm{kg}$ fertilizer $\mathrm{N}$ applied, from 14 to $57 \mathrm{~kg}$ grain per $\mathrm{kg}$ fertilizer $\mathrm{P}$ applied, and from 4 to $24 \mathrm{~kg}$ grain per $\mathrm{kg}$ fertilizer $\mathrm{K}$ applied. The low AE measured in the NPK treatment plots was due to the very high rates of fertilizer applied in these plots to make sure that nutrients are not limiting yield. Nitrogen use efficiency was improved with more appropriate fertilizer $\mathrm{N}$ rates and better timing of $\mathrm{N}$ application practiced in the SSNM treatments.

\section{Yield Comparison}

Data on grain yield from the various treatments (Table 3) shows that on average, grain yields in omission plots increased in the order PK $(5.9 \mathrm{Mg}$ $\left.\mathrm{ha}^{-1}\right)<\mathrm{NP}\left(7.8 \mathrm{Mg} \mathrm{ha}^{-1}\right)<\mathrm{NK}\left(7.9 \mathrm{Mg} \mathrm{ha}^{-1}\right)$. This shows that $\mathrm{N}$ is the most limiting nutrient affecting maize yield, whereas $\mathrm{P}$ and $\mathrm{K}$ supply are equally limiting factors.

Across sites, attainable yields measured in NPK and SSNM plots on average ranged from $7.4 \mathrm{Mg}$ $\mathrm{ha}^{-1}$ to $10.9 \mathrm{Mg} \mathrm{ha}^{-1}$ while yields in the FFP plot on average ranged from $6.4 \mathrm{Mg} \mathrm{ha}^{-1}$ to $8.7 \mathrm{Mg} \mathrm{ha}^{-1}$. This clearly shows that a substantial yield gap of about 1 to $2 \mathrm{Mg} \mathrm{ha}^{-1}$ exists between farmers' actual yield and what is attainable with optimal crop and nutrient management. Differences in grain yield among the seasons are mainly attributed to seasonal fluctuations in climate and other environmental factors. In the case of crop 3, the high yields attained even in the omission plots are attributed to the long dry period before the maize cropping season which enabled crop residues to decompose and become available to the maize crop.

In general, ICM treatments resulted in higher yields compared to plots without ICM. This indicates that ICM, mainly liming, had a positive effect in the 
Table 3. Yield Comparison among the treatments for three seasons.

\begin{tabular}{llll}
\hline \multirow{2}{*}{ Treatments } & \multicolumn{3}{c}{ Grain Yield $\left(\mathrm{Mg} \mathrm{ha}^{-1}\right)$} \\
\cline { 2 - 4 } & Season 1 & Season 2 & Season 3 \\
\hline PK & $4.78 \mathrm{e}$ & $5.0 \mathrm{f}$ & $7.1 \mathrm{f}$ \\
PK+ICM & $5.47 \mathrm{de}$ & $5.9 \mathrm{ef}$ & $7.4 \mathrm{ef}$ \\
NK & $6.73 \mathrm{abc}$ & $7.1 \mathrm{de}$ & $9.1 \mathrm{bcd}$ \\
NK+ICM & $7.18 \mathrm{ab}$ & $8.1 \mathrm{bcd}$ & $9.1 \mathrm{bcd}$ \\
NP & $5.83 \mathrm{cde}$ & $7.4 \mathrm{~cd}$ & $8.5 \mathrm{def}$ \\
NP+ICM & $7.15 \mathrm{ab}$ & $8.6 \mathrm{abc}$ & $9.2 \mathrm{bcd}$ \\
NPK & $7.40 \mathrm{ab}$ & $9.1 \mathrm{ab}$ & $10.9 \mathrm{a}$ \\
NPK+ICM & $7.72 \mathrm{a}$ & $9.4 \mathrm{a}$ & $10.3 \mathrm{ab}$ \\
SSNM & - & $8.4 \mathrm{abc}$ & $10.1 \mathrm{ab}$ \\
SSNM+ICM & - & $8.9 \mathrm{ab}$ & $10.1 \mathrm{ab}$ \\
FFP & $6.41 \mathrm{bcd}$ & $7.0 \mathrm{de}$ & $8.7 \mathrm{cde}$ \\
FFP+ICM & $7.02 \mathrm{ab}$ & - & - \\
\hline CV $(\%)$ & 12.02 & 12.2 & 11.6 \\
\hline
\end{tabular}

Note: SSNM = Site Specific Nutrient Management, ICM = Improve crop management, and FFP = Farmers' Fertilizer Practice. Number followed by the same letters in each column is not significant different at 5\% DMRT.

soil reaction particularly in increasing the availability of nutrients to the plant.

Grain yield in the NPK plots was on average 0.5 $\mathrm{Mg} \mathrm{ha}^{-1}$ higher than in SSNM plots although this difference is not statistically significant. This shows that the nutrient management strategy employed in the SSNM treatment can give equally high yields as the NPK plot. Grain yield in SSNM was significantly higher than the FFP in both season 2 and season 3. On average, SSNM generated a yield gain of $1.5 \mathrm{Mg}$ $\mathrm{ha}^{-1}(19 \%)$ over the FFP. This clearly indicates that SSNM provides substantial opportunities for farmers to increase productivity and profitability of maize through improved crop and nutrient management strategies.

\section{CONCLUSIONS}

Soil fertility in the experimental site is very low that indicated by the low of $\mathrm{C}$ organic, $\mathrm{N}$ total, and $\mathrm{K}$ exchangeable except $\mathrm{P}$ available, thus the organic matter, $\mathrm{N}$, and $\mathrm{K}$ fertilizer are required to achieve the yield maize under favorable weather conditions in Lampung.

There are substantial opportunities for maize farmers in Lampung to increase their productivity and profitability with SSNM. Yield increases of about 1.5 $\mathrm{Mg} \mathrm{ha}^{-1}$ over current farmer fertilizer practice can be achieved with improved timing of $\mathrm{N}$ application and more balanced fertilizer use in SSNM. Yield responses of about 2.3-4.1 $\mathrm{Mg} \mathrm{ha}^{-1}, 0.6-2.0 \mathrm{Mg} \mathrm{ha}^{-1}$, 0.3-2.4 $\mathrm{Mg} \mathrm{ha}^{-1}$ can be expected with the application of fertilizer N, P, and K, respectively. Yield responses, particularly to fertilizer $\mathrm{N}$, are highly variable among fields and/or seasons. Thus, the SSNM strategy for nitrogen with total $\mathrm{N}$ rate, split $\mathrm{N}$ applications, and dynamic $\mathrm{N}$ management provides assurance that additional yield can be attained in years more favorable than the average.

\section{REFERENCES}

Cassman KG, S Peng, DC Olk, JK Ladha, W Reichardt, A Dobermann and U Singh. 1998. Opportunities for increased nitrogen use efficiency from improved resource management in irrigated rice system. Field Crops Res 56:7-78.

Dobermann A, CA Witt, D Dawe, GC Gines, R Nagarajan, S Satawathananont, TT Son, PS Tan, GH Wang, NV Chient, VTK Thoa, CV Phung, P Stalin, P Muthukrishnan, V Ravi, M Babu, S Chatuporn, M Kongchum, Q Sun, R Fu, GC Simbahan and MAA Adviento. 2002. Site specific nutrient management for intensive rice cropping systems in Asia. Field crops Res 74: 37-66.

Ferguson RB, GW Hergert, JS Schepers, CA Gotway, JE Cahoon and TA Peterson. 2002. Site-specific nitrogen management of irrigated maize: Yield and Soil residual nitrate effect. Soil Sci Soc Am J 66: 544-552.

Gale WJ and CA Cambardella. 2000. Carbon Dynamics of Surface Residue- and Root-derived Organic Matter under Simulated No-till. Soil Sci Soc Am J 64:190195.

Lampung in Figure. 2006. Area harvested and production of maize in Lampung. BPS. Propinsi Lampung.

Isa AF, K Nugroho, Sukarman and F Agus. 2005. Soil profile description: Site-specific nutrient management for maize in experimental sites in North Sumatera, Lampung, Central Java, East Java and South Sulawesi. Indonesian Soil Research Institute In Collaboration with PPI/PPIC and IP Southeast Asia Program, 54p.

Swastika DKS, F Kasim, W Sudana, R Hendayana, K Suhariyanto, RV Gerpacio and PL Pingali. 2004. Maize in Indonesia: Production system, constraints, and Research priorities. (CIMMYT. www.cimmyt.org.), 34p.

Witt CA and A Dobermann. 2002. A site specific nutrient management approach for irrigated, lowland rice in Asia. Better Crops Int 16: 20-24.

Zibilske LM and JM Bradford. 2007. Soil Aggregation, Aggregate Carbon and Nitrogen, and Moisture Retention Induced by Conservation Tillage. Soil Sci Soc Am J 71: 793-802. 